\title{
DAMPAK PELATIHAN KONSTRUKSI BANGUNAN TAHAN GEMPA TERHADAP PERBAIKAN KINERJA BURUH BANGUNAN
}

\author{
Nanang Dalil Herman, Dewi Yustiarini ${ }^{2}$, Johar Maknun ${ }^{3}$, Tjahyani Busono ${ }^{4}$
}

\begin{abstract}
Abstrak: Penelitian ini bertujuan untuk memperbaiki kinerja buruh bangunan dalam pemahaman dan pengetahuan tentang bangunan melalui program pelatihan konstruksi bangunan tahan gempa. Hasil penelitian diperoleh bahwa melalui pelatihan diperoleh peningkatan terhadap pengetahuan buruh bangunan mengenai konstruksi bangunan tahan gempa sebesar 41\% (empat puluh satu persen).
\end{abstract}

\begin{abstract}
This research aim to re-build labours capacity on concept and knowledge about housing through construction workshop in endure building from earthquake. The result from this research found that knowledge of participant had been increase to $41 \%$ (fourty one percents) through the workshop.
\end{abstract}

Kata Kunci: pelatihan, buruh bangunan, bangunan tahan gempa

\section{PENDAHULUAN}

Letak geografis Indonesia dipandang dari sudut geologis merupakan daerah rawan terjadinya bencana terutama bencana geologi. Wilayah Indonesia terletak pada tiga lempeng tektonik di dunia yaitu: lempeng Australia di selatan, lempeng Euro-Asia di barat dan lempeng Samudra Pasifik di timur yang dapat menunjang terjadinya sejumlah bencana. Berdasarkan posisi tersebut, hampir seluruh wilayah Indonesia rawan terhadap terjadinya bencana, kecuali daerah kalimantan yang relatif stabil. Kejadian bencana akan Sangat mungkin terjadi setiap saat dan sukar diperkirakan kapan dan dimana persisnya bencana tersebut akan terjadi.

Kerusakan dan kehilangan sesuatu yang berkaitan dengan kehidupan dan penghidupan manusia adalah akibat yang ditimbulkan dari terjadinya bencana. Secara konseptual yang cukup mendasar dari hasil analisis dan evaluasi, beberapa akibat bencana adalah: (1) Aset fisik yang memerlukan perbaikan atau perlu pembangunan kembali; (2) Tidak dapat berfungsinya segala sesuatu sebelum mendapat penanganan kembali dalam bentuk perbaikan atau pembangunan kembali; dan (3) Banyaknya anggota masyarakat yang mengalami trauma (gangguan) yang perlu mendapatkan bantuan khusus agar kembali menjalani kehidupan secara normal.

Kerusakan bangunan yang diakibatkan oleh bencana alam disebabkan oleh mutu bahan yang rendah dan teknik membangun yang tidak sesuai dengan kaidah konstruksi. Buruh bangunan merupakan ujung tombak dalam pelaksanaan pembangunan. Pengetahuan dan pemahaman buruh bangunan yang kurang terhadap teknik membangun akan menyebabkan kualitas bangunan yang rendah. Pada daerah yang rawan gempa pengetahuan dan pemahaman buruh bangunan mengenai konstruksi bangunan tahan gempa merupakan hal yang sangat

\section{0}

${ }^{1}$ Dewi Yustiarini adalah Dosen pada Jurusan Pendidikan Teknik Sipil FPTK UPI

${ }^{2}$ Nanang Dalil H adalah Dosen pada Jurusan Pendidikan Teknik Sipil FPTK UPI

${ }^{3}$ Johar Maknun adalah Dosen pada Jurusan Pendidikan Teknik Arsitektur FPTK UPI

${ }^{4}$ Tjahyani Busono adalah Dosen pada Jurusan Pendidikan Teknik Sipil FPTK UPI penting. Peningkatan kompetensi buruh bangunan dapat dilaksanakan melalui program pelatihan konstruksi bangunan tahan gempa. Pelatihan peningkatan kompetensi buruh bangunan tentang teknik membangun sesuai kaidah konstruksi bangunan tahan gempa merupakan salah satu strategi pengurangan (mitigasi) risiko bencana.

\section{LANDASAN TEORI}

\section{Konstruksi Bangunan Tahan Gempa}

Bangunan yang didesain tahan gempa pada prinsipnya harus menjamin keamanan dan kenyamanan pengguna bangunan. Untuk menghasilkan bangunan yang berkualitas harus didukung oleh penggunaan material yang bermutu dan tenaga kerja yang terampil. Hasil akhir yang diharapkan dari bangunan tahan gempa ini adalah tercapainya kinerja bangunan, yaitu:

a. Bangunan tidak mengalami kerusakan pada elemen struktural maupun non-struktural saat terjadi gempa ringan.

b. Pada saat terjadi gempa sedang, bangunan boleh mengalami kerusakan yang dapat diperbaiki pada elemen non-struktural, sedangkan elemen struktural tidak boleh mengalami kerusakan.

c. Pada saat terjadi gempa kuat, bangunan boleh mengalami kerusakan pada elemen struktural dan non-struktural, tetapi bangunan tidak boleh runtuh.

Adapun elemen struktural tersebut berupa: kolom, balok, kuda-kuda, sambungan, dan elemen non struktural berupa: dinding bata biasa, atap, jendela, pintu, dan ventilasi. Acuan yang digunakan adalah SNI - 03 - 1726 - 2002 (revisi) tentang "Tata Cara Perencanaan Ketahanan Gempa untuk Rumah dan Gedung”.

Program Pelatihan Konstruksi Bangunan Tahan Gempa 
Pendidikan dan pelatihan merupakan satu keterpaduan yang cukup sulit untuk dipisahkan sebab dalam kegiatan kedua-duanya selalu berkaitan dan melengkapi. Bahkan pada prakteknya kadang-kadang batas antara pendidikan dan pelatihan tidak ada garis yang tegas (Atmodjo,1998). Dubois dan Mayo (1987) mengemukakan pendidikan perlu dibedakan dengan pelatihan dari orientasinya. Pendidikan lebih luas mencakup kemampuan umum sedangkan pelatihan lebih berorientasi pada tugas dan tujuan khusus.

Prinsip-prinsip perencanaan pelatihan dan pengembangan pada orang dewasa merujuk pada Mc Ghee (Mangkunegara, 2000) adalah:

a) materi harus diberikan secara sistematis dan berdasarkan tahapan-tahapan.

b) tahapan-tahapan tersebut harus disesuaikan dengan tujuan yang hendak dicapai.

c) penatar harus mampu memotivasi dan menyebarkan respon yang berhubungan dengan serangkaian materi pelajaran.

d) adanya penguat (reinforcement) guna membangkitkan respon yang positif dari peserta.

e) menggunakan konsep pembentukan (shaping) perilaku.

Komponen-komponen pembelajaran (Slameto, 1999; Rivai dan Sudjana, 2005; Hamalik, 1999) terdiri dari tujuan, peserta didik, tenaga kependidikan, materi, metode/teknik, media dan evaluasi. Komponen tersebut saling mempengaruhi dan berkaitan dalam pembelajaran. Oleh karena itu pembelajaran akan efektif dan efisien apabila komponen tersebut memiliki kriteria yang baik. .

\section{PENYUSUNAN PROGRAM PELATIHAN}

Program pelatihan untuk buruh bangunan telah dilakukan pada beberapa wilayah di Indonesia. Khusus pelatihan yang terakhir untuk tahun 2009 dilakukan di salah satu Kecamatan di Propinsi Sumatera Barat. Propinsi paling barat di Pulau Sumatera ini dipilih karena termasuk wilayah rawan gempa bumi. Penyusunan dan pengembangan program pelatihan dibagi menjadi dua tahap, yaitu:

Tahap pertama pengumpulan data. Teknik pengumpulan data sebagai studi awal terdiri dari:

1. Observasi

Observasi merupakan pengamatan dan pencatatan sistematis terhadap gejala-gejala yang diteliti. Observasi digunakan untuk mengetahui kondisi existing lokasi penelitian.

2. Wawancara

Wawancara merupakan kegiatan tanya jawab antara dua orang atau lebih antara pewawancara dengan responden. Kegiatan wawancara digunakan untuk mengetahui pengetahuan awal buruh bangunan mengenai teknik membangun dan miskonsepsi pengetahuan buruh bangunan dengan kaidah konstruksi.

3. Dokumentasi

Dokumentasi adalah pengumpulan data melalui dokumen-dokumen. Digunakan untuk memperoleh bahan pustaka untuk menyusun modul atau bahan ajar yang akan dibagikan kepada peserta didik pelatihan konstruksi bangunan tahan gempa.

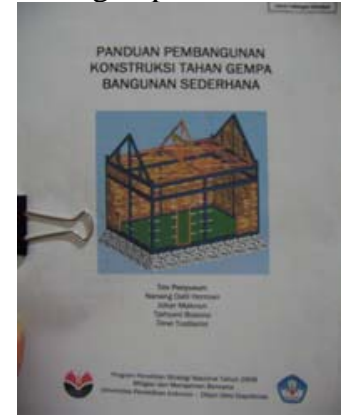

Gambar 1. Buku panduan

Tahap kedua mengembangkan komponenkomponen pembelajaran, terdiri dari:

1. Menyusun jadwal pelatihan

Jadwal pelatihan disusun untuk menetapkan waktu yang tepat antara penyelenggara pelatihan dan peserta didik. Pelatihan dijadwalkan selama dua hari.

2. Menetapkan jumlah peserta didik

Jumlah peserta didik diperoleh dari hasil observasi dan wawancara yang telah dilakukan pada tahap pertama. Target peserta didik minimal berjumlah 30 (tiga puluh) orang.

3. Menetapkan tenaga kependidikan

Tenaga kependidikan untuk pelatihan konstruksi bangunan tahan gempa ditetapkan dari tenaga ahli yang berpengalaman dalam memberikan pelatihan sejenis.

4. Materi

Materi untuk pelatihan disusun secara sistematis, terdiri dari:

a. Materi kegempaan.

b. Materi mitigasi bencana gempa bumi dan

c. Materi konstruksi bangunan tahan gempa.

5. Metode/teknik pelatihan

Metode pelatihan terdiri dari penyampaian materi pelajaran, praktek di lapangan, diskusi, dan diselingi pemutaran video konstruksi bangunan tahan gempa. Target praktek diharapkan sampai kepada membuat penulangan dan pemasangan bata. dan praktek diselingi dengan diskusi

6. Media berupa Peralatan Audiovisual

Peralatan audio visual merupakan peralatan yang dapat membantu untuk melihat gambaran dan situasi yang nyata seperti melalui pemotretan. Digunakan untuk memperoleh data kondisi 
existing lokasi penelitian dan implementasi program pelatihan konstruksi bangunan tahan gempa.

7. Evaluasi
a. Tes belajar
Digunakan untuk mengetahui gambaran kompetensi buruh bangunan sebelum dan sesudah mengikuti kegiatan implementasi program pelatihan konstruksi bangunan tahan gempa.
Digunakan untuk menjaring pendapat peserta pelatihan mengenai keunggulan dan kelemahan program pelatihan konstruksi bangunan tahan gempa.
b. Angket

\section{IMPLEMENTASI PROGRAM PELATIHAN}
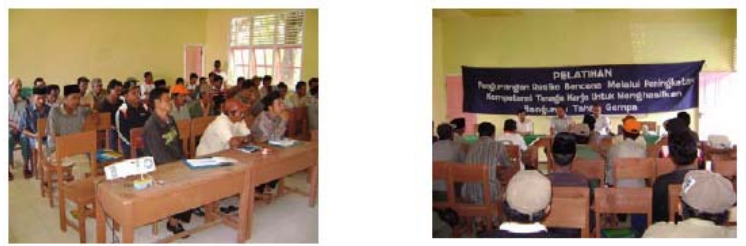

Gambar 2. Implementasi pelatihan

Pelatihan dilaksanakan selama 2 hari dengan peserta pelatihan dari buruh bangunan yang berjumlah lebih dari 30 (tiga puluh) orang. Hari pertama dijadwalkan khusus untuk pemberian materi dari tenaga ahli. Pemberian materi diselingi dengan tanya jawab. Sebelum penyampaina maeri, dilakukan tes awal kepada peserta didik buruh bangunan. Tujuan tes awal untuk mengetahui pengetahuan buruh bangunan tentang konstruksi bangunan sebelum diberikan materi.

Pelatihan hari kedua diisi dengan peninjauan lapangan dan praktek konstruksi bangunan berdasarkan materi yang telah diberikan sehari sebelumnya. Pada hari terkahir pelatihan dilakukan tes akhir dan pembagian angket. Tes akhir bertujuan untuk mengetahui pemahaman buruh bangunan terhadap konstruksi bangunan selama dua hari pelatihan. Sedangkan angket bertujuan untuk perbaikan kinerja penyelenggara terhadap pelatihan sejenis. Dari evaluasi berupa tes dapat diperoleh hasil adanya peningkatan kinerja buruh bangunan sebelum dan sesudah dilakukan pelatihan konstruksi bangunan tahan gempa.

\section{Hasil Uji Coba Program Pelatihan}

\section{Pengetahuan Awal Buruh Bangunan}

Gambaran umum pengetahuan awal buruh bangunan di Kecamatan Lunang Silaut Kabupaten Pesisir Selatan Propinsi Sumatera Barat tertera pada Gambar 3.

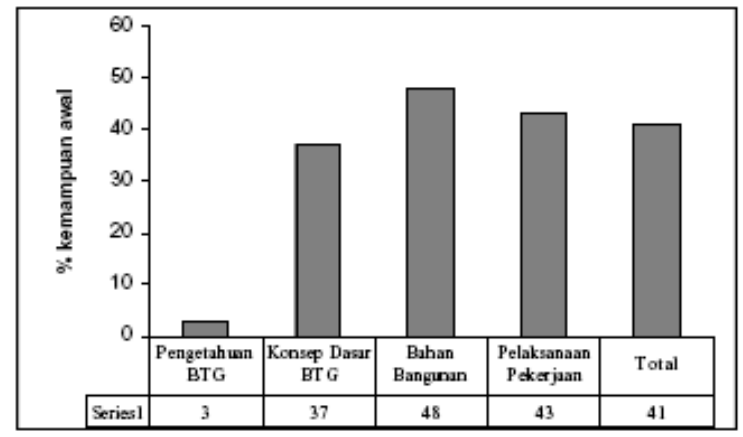

Gambar 3. Gambaran Umum Pengetahuan Awal Buruh Bangunan

Pengetahuan awal buruh bangunan didasarkan pada 4 (empat) indikator. Secara umum pengetahuan awal buruh bangunan mengenai konstruksi bangunan tahan gempa berada pada persentil 41\%. Ini menunjukkan bahwa pengetahuan mereka mengenai konstruksi bangunan tahan gempa masih tergolong rendah. Hal ini dimungkinkan karena karena tidak ada buruh bangunan yang pernah mendapatkan pendidikan khusus mengenai teknik bangunan, misalnya dari SMK/STM bangunan. Mereka memperoleh pengetahuan mengenai teknik/cara-cara membangunan secara turun-temurun. Posisi mereka biasanya meningkat secara bertahap, mula-mula mereka menjadi laden setelah beberapa tahun kemudian meningkat menjadi tukang dan selanjutnya menjadi kepala tukang.

Gambaran umum pengetahuan awal buruh bangunan berdasarkan indikator secara berurutan adalah sebagai berikut :

a. Pengetahuan mengenai istilah bangunan tahan gempa

Pengetahuan mengenai istilah bangunan tahan gempa merupakan indikator yang paling rendah dimiliki buruh bangunan. Dari 39 peserta pelatihan hanya 3\% yang telah mengenal istilah bangunan tahan gempa, sedangkan $97 \%$ belum mengenal istilah tersebut.

b. Konsep dasar bangunan tahan gampa

Buruh bangunan yang sudah mengetahui dan memahami konsep dasar bangunan tahan gempa sebesar 37\% yang termasuk kategori rendah. Ini dikarenakan mereka tidak pernah mendapatkan pelatihan atau penyuluhan mengenai konstruksi bangunan tahan gempa, merekan mendapatkan pengetahuan teknik membangun secara turuntemurun yang tidak memperhatikan kaidah konstruksi bangunan tahan gempa.

c. Pelaksanaan pekerjaan untuk menghasilkan bangunan tahan gempa 
Buruh bangunan yang sudah mengetahui dan melaksanakan teknik-teknik membangun untuk menghasilkan bangunan tahan gempa sebesar 43\% yang termasuk kategori rendah. Hal ini dikarenakan mereka belum pernah mendapatkan pelatihan mengenai teknik-teknik pelaksanaan pembangunan untuk menghasilkan konstruksi bangunan tahan gempa.

d. Pengetahuan mengenai bahan bangunan

Pengetahuan awal buruh bangunan mengenai bahan bangunan merupakan pengetahuan awal terbaik yang sudah dimiliki oleh mereka. Ada $48 \%$ peserta pelatihan yang sudah memiliki pengetahuan awal yang baik mengenai pemilihan bahan bangunan untuk menghasilkan bangunan tahan gempa.

\section{Miskonsepsi Teknik Membangun Sesuai Kaidah Konstruksi}

Novak (1984 : 20) mendefinisikan miskonsepsi sebagai suatu interpretasi konsep-konsep dalam suatu pernyataan yang tidak dapat diterima. Suparno (1998 : 95) memandang miskonsepsi sebagai pengertian yang tidak akurat akan konsep, penggunaan konsep yang salah, klasifikasi contohcontoh yang salah, kekacauan konsep-konsep yang berbeda dan hubungan hierarkis konsep-konsep yang tidak benar. Dari pengertian di atas miskonsepsi dapat diartikan sebagai suatu konsepsi yang tidak sesuai dengan pengertian ilmiah atau pengertian yang diterima oleh para ilmuwan.

Miskonsepsi didefinisikan sebagai konsepsi siswa yang tidak cocok dengan konsepsi para ilmuwan, hanya dapat diterima dalam kasus-kasus tertentu dan tidak berlaku untuk kasus-kasus lainnya serta tidak dapat digeneralisasi. Konsepsi tersebut pada umumnya dibangun berdasarkan akal sehat (common sense) atau dibangun secara intuitif dalam upaya memberi makna terhadap dunia pengalaman mereka sehari-hari dan hanya merupakan eksplanasi pragmatis terhadap dunia realita. Miskonsepsi siswa mungkin pula diperoleh melalui proses pembelajaran pada jenjang pendidikan sebelumnya (Sadia, 1996:13).

Penyebab dari resistennya sebuah miskonsepsi karena setiap orang membangun pengetahuan persis dengan pengalamannya. Sekali kita telah membangun pengetahuan, maka tidak mudah untuk memberi tahu bahwa hal tersebut salah dengan jalan hanya memberi tahu untuk mengubah miskonsepsi itu. Jadi cara untuk mengubah miskonsepsi adalah dengan jalan mengkonstruksi konsep baru yang lebih cocok untuk menjelaskan pengalaman kita (Bodner, 1986 : 14).
Gambaran miskonsepsi mengenai teknik membangun sesuai kaidah konstruksi dikelompokkan menjadi 3, yaitu :

\section{a. Konsep dasar bangunan tahan gempa}

Gambaran miskonsepsi buruh bangunan di Kecamatan Lunang Silaut mengenai konsep dasar bangunan tahan gempa secara rinci tertera pada Gambar 4.

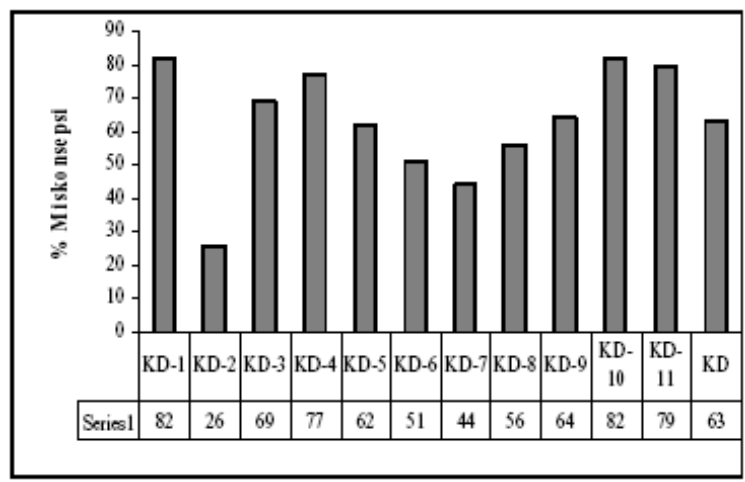

Gambar 4. Gambaran Miskonsepsi konsep dasar bangunan tahan gempa

Miskonsepsi buruh bangunan mengenai konsep dasar bangunan tahan gempa sebesar 63\%, artinya kesalahan-kesalahan membangun bangunan yang dilaksanakan oleh buruh bangunan masih cukup tinggi. Miskonsepsi terbesar yaitu sebesar $82 \%$ adalah mengenai bentuk disain bangunan yang tahan terhadap gempa. Dalam membangun karena tidak disertai gambar, pemilik bangunan biasanya menyerahkan penuh pelaksanaan pembangunan kepada kepala tukang. Mereka biasanya membuat denah/bentuk bangunan sesuai dengan kondisi lahan yang ada tanpa banyak melakukan rekayasa, karena mereka tidak memiliki pemahaman yang baik mengenai bentuk-bentuk bangunan.

\section{b. Pelaksanaan pekerjaan untuk menghasilkan bangunan tahan gempa}

Gambaran miskonsepsi buruh bangunan di Kecamatan Lunang Silaut mengenai pelaksanaan pekerjaan untuk menghasilkan bangunan tahan gempa secara rinci tertera pada Gambar 5 


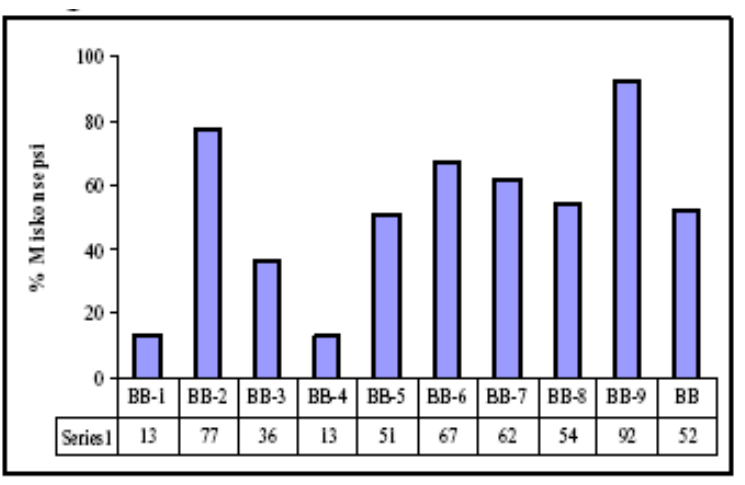

Gambar 5. Gambaran Miskonsepsi pelaksanaan pekerjaan

.Miskonsepsi pelaksanaan pekerjaan untuk menghasilkan bangunan tahan gempa sebesar 52\%, hal ini lebih rendah dari pemahaman mengenai konsep dasar bangunan tahan gempa, tetapi miskonsepsi dalam pelaksanaan pekerjaan masih di atas 50\%, artinya ini masih memerlukan perhatian yang sungguh-sungguh. Pelaksanaan pembangunan merupakan faktor penting yang harus diperhatikan, karena pelaksanaan pembangunan merupakan ujung tombak keberhasilan dalam pembangunan tahan gempa. Miskonsepsi terbesar dalam pelaksanaan pembangunan adalah berkaitan dengan cara/teknik membuat sambungan kayu yaitu 92\%, hal ini terjadi karena buruh bangunan dalam membuat sambungan kayu selalu menggunakan paku, hal ini tidak sejalan dengan konsep bangunan tahan gempa. Miskonsepsi terkecil sebesar $13 \%$ yaitu mengenai penggunaan lot yang berfungsi untuk mendapatkan posisi tegak lurus antara dinding dan kolom. Hal ini dikarenakan mereka sudah biasa menggunakan lot untuk mendapatkan posisi tegak tersebut. Ini juga menunjukkan bahwa buruh bangunan mendapatkan pengetahuan mengenai teknik-teknik membangun secara turun-temurun tanpa ada pelatihan khusus yang diberikan oleh instansi terkait untuk meningkatkan kompetensi mereka mengenai teknik membangun yang benar sesuai kaidah konstruksi.

c. Pengetahuan bahan bangunan

Gambaran miskonsepsi buruh bangunan di Kecamatan Lunang Silaut mengenai pengetahuan bahan bangunan untuk menghasilkan bangunan tahan gempa secara rinci tertera pada Gambar 6.

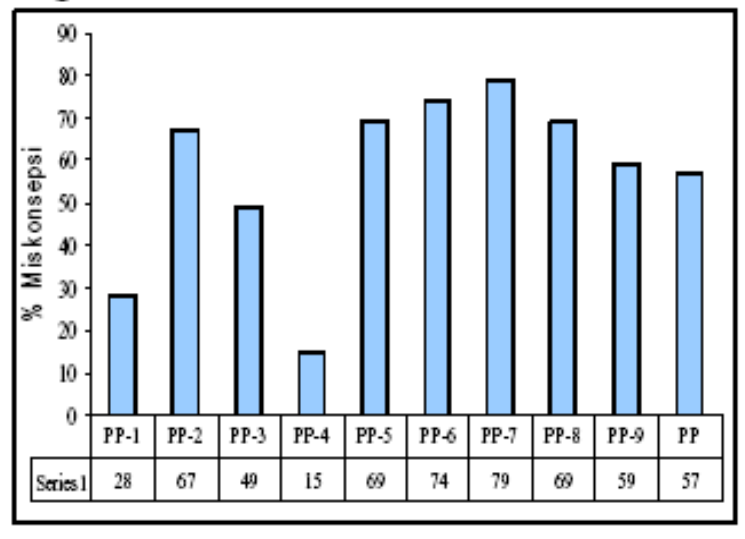

Gambar 6. Gambaran Miskonsepsi pengetahuan bahan bangunan

Miskonsepsi pengetahuan bahan bangunan sebesar 57\%, ini menunjukkan masih terjadi salah konsep dalam hal bahan bangunan, terutama mengenai pemilihan bahan bangunan yang cocok berdasarkan ketentuatn yang berlaku. Miskonsepsi terbesar sebesar $79 \%$ adalah pengetahuan mengenai sifat kayu yang memiliki sifat susut yang tinggi. Buruh bangunan jarang memperhatikan kondisi kandungan air dalam kayu tersebut, mereka sering menggunakan kayu yang baru digergaji, hal ini akan menimbulkan bahaya karena kayu memiliki sifat susut yang tinggi. Miskonsepsi terkecil adalah mengenai persyaratan batu bata yang baik. Sebagian besar dari mereka sudah mengetahui mengenai persyaratan batu bata yang baik, hanya 15\% saja yang masih mengalami miskonsepsi.

\section{Peningkatan Kompetensi Buruh Bangunan Melalui Kegiatan Pelatihan}

Gambaran hasil pelatihan konstruksi bangunan tahan gempa di Kecamatan Lunang Silaut secara rinci tertera pada Gambar 7.

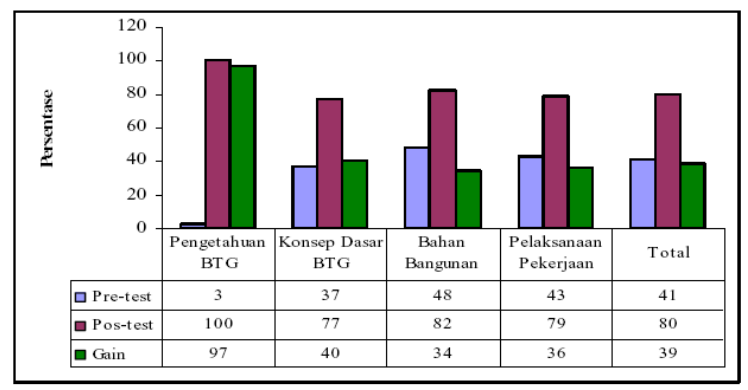

Gambar 7. Gambaran Umum Hasil Kegiatan Pelatihan

Secara umum hasil kegiatan pelatihan telah dapat meningkatkan pengetahuan buruh bangunan mengenai konstruksi bangunan tahan gempa sebesar 
39\%. Pengetahuan awal mereka sebelum kegiatan pelatihan sebesar $41 \%$ dan setelah mengikuti kegiatan pelatihan sebesar $80 \%$. Hal ini menunjukkan bahwa kegiatan pelatihan telah memberikan dampak positif dalam meningkatkan pemahaman buruh bangunan mengenai konstruksi bangunan tahan gempa. Gambaran hasil penelitian untuk masingmasing indikator adalah sebagai berikut :

a. Pengetahuan mengenai istilah bangunan tahan gempa

Sebelum mengikuti kegiatan pelatihan, dari 39 peserta pelatihan hanya 3\% yang telah mengenal istilah bangunan tahan gempa, sedangkan setelah mengikuti pelatihan seluruh peserta (100\%) telah mengenal istilah bangunan tahan gempa tersebut. Jadi kegiatan pelatihan telah memberikan dampak dalam meningkatkan pengetahuan buruh bangunan mengenai istilah bangunan tahan gempa. Pengetahuan mengenai istilah ini diharapkan akan mempengaruhi buruh bangunan dalam kegiatan pelaksanaan pembangunan

b. Konsep dasar bangunan tahan gampa

Buruh bangunan yang sudah mengetahui dan memahami konsep dasar bangunan tahan gempa sebelum kegiatan pelatihan sebesar 37\% yang termasuk kategori rendah. Ini dikarenakan mereka tidak pernah mendapatkan pelatihan atau penyuluhan mengenai konstruksi bangunan tahan gempa, merekan mendapatkan pengetahuan teknik membangun secara turun-temurun yang tidak memperhatikan kaidah konstruksi bangunan tahan gempa. Setelah mengikuti kegiatan pelatihan pengetahuan dan pemahaman buruh bangunan mengenai konsep dasar bangunan tahan gempa mengalami peningkatan sebesar $40 \%$, yaitu dari pengetahuan awal sebesar 37\% menjadi $77 \%$.

c. Pelaksanaan pekerjaan untuk menghasilkan bangunan tahan gempa

Buruh bangunan yang sudah mengetahui dan melaksanakan teknik-teknik membangun untuk menghasilkan bangunan tahan gempa sebelum kegiatan pelatihan sebesar $43 \%$ yang termasuk kategori rendah.
Hal ini dikarenakan mereka belum pernah mendapatkan pelatihan mengenai teknik-teknik pelaksanaan pembangunan untuk menghasilkan konstruksi bangunan tahan gempa. Setelah mengikuti kegiatan pelatihan pengetahuan mereka meningkat menjadi 79\%, artinya kegiatan pelatihan telah memberikan dampak sebesar 36\% dalam meningkatkan pengetahuan dan pemahaman mengenai teknik-teknik membangun untuk menghasilkan bangunan tahan gempa.

d. Pengetahuan mengenai bahan bangunan

Pengetahuan awal buruh bangunan mengenai bahan bangunan sebelum kegiatan pelatihan sebesar 48\% setelah kegiatan pelatihan pengetahuan mereka meningkat menjadi 82\%. Artinya kegiatan pelatihan telah memberikan dampak sebesar 34\% dalam meningkatkan pengetahuan mengenai bahan bangunan yang baik untuk menghasilkan bangunan tahan gempa.

\section{KESIMPULAN}

1. Pada umumnya buruh bangunan bekerja berdasarkan pengalaman tanpa dilandasi oleh teori.

2. Pelatihan ini memberikan materi dan praktek yang dapat memperbaiki kinerja buruh dalam melakukan pekerjaan mereka.

3. Perbaikan kinerja buruh akan menghasilkan sumberdaya manusia yang lebih baik dari sebelumnya, khususnya dalam membangun bangunan tahan gempa sehingga masyarakat menjadi lebih nyaman menjalani kehidupan.

\section{DAFTAR PUSTAKA}

Boen, Teddy. 2007. Tata Cara Pembangunan Rumah Sederhana Tahan Gempa. Jakarta : Word Seismic Safety Initiative (WWSI).

NN, Perencanaan Bangunan Sederhana Tahan Gempa Modul C_4. Jakarta : Departemen Pekerjaan Umum.

KPP Mitigasi Bencana ITB. 2003. Program Kesiapan Sekolah Terhadap Bahaya Gempa Buku 1,2,dan 3. Jakarta : Ditejen Mandikdasmen Depdiknas.

Tarumingkeng, RC. (2005), "Peran Strategis Manajemen Sumber Daya Manusia”, http://tumoutou.net/STRAT_PSDM.htm 